Final article:

Lindgreen, A., Hingley, M.K., Grant, D.B., and Morgan, R. (2012), "Value in business and industrial marketing: past, present, and future", Industrial Marketing Management, Vol. 41, No. 1, pp. 207-214. (ISSN 0019-8501)

For full article, please contact LindgreenA@ cardiff.ac.uk

Value in Business and Industrial Marketing: Past, Present, and Future

Industrial Marketing Management

Special issue: "Value in business and industrial marketing"

\author{
Adam Lindgreen ${ }^{1,2}$ \\ Cardiff Business School \\ Cardiff University \\ Aberconway Building \\ Colum Drive \\ Cardiff CF10 3EU \\ U.K. \\ E-mail: LindgreenA@cardiff.ac.uk
}

\author{
Martin K. Hingley \\ Lincoln Business School \\ University of Lincoln \\ Brayford Pool \\ Lincoln LN6 7TS \\ U.K.
}

E-mail: mhingley@ lincoln.ac.uk

\author{
David B. Grant \\ Logistics Institute \\ University of Hull Business School \\ Hull HU6 7RX \\ U.K. \\ E-mail: d.grant@hull.ac.uk \\ Robert E. Morgan \\ Cardiff Business School \\ Cardiff University \\ Aberconway Building \\ Colum Drive \\ Cardiff CF10 3EU
}

\footnotetext{
${ }^{1}$ Corresponding author.

${ }^{2}$ The authors contributed equally.
} 
U.K.

E-mail: MorganRE@cardiff.ac.uk 


\section{Highlights}

Presents a review of literature on value in business and industrial marketing using Lindgreen \& Wynstra's (2005) framework. Highlights changes in notions of value that help to identify areas driving future research. Presents a process model for value orchestration in business and industrial marketing. Discusses the activities of structuring activities, bundling activities, and leveraging of resources that form the basis of value orchestration. 


\title{
Value in Business \& Industrial Marketing: Past, Present, \& Future
}

\begin{abstract}
This article offers an overview of research on the 'value' that businesses and industrial marketers analyze, create, and deliver. First, value literature (up to and around 2005 and post $2005)$ is discussed. This review highlights the changes in our notions of value and helps to identify seven areas for consideration that should drive future research: value proposition, relationship form, capabilities management, value metrics, temporal horizon, innovation imperative, and tactical focus. Following this depiction of value analysis, value creation, and value delivery, we present a process model for value orchestration in business and industrial marketing. Three activities collectively form the basis of value orchestration, namely structuring activities, bundling activities, and leveraging of resources.
\end{abstract}

Keywords: analysis, business marketing, creation, delivery, industrial marketing, relationships, transactions, value. 


\section{Introduction}

The creation of value is paramount to any company's survival (Kotler \& Keller, 2008), especially when dramatic changes lead to fundamental shifts in what companies analyze, create, and deliver (Doyle, 2000; Hunt, 2000). And yet academics and practitioners alike agree that we have only just begun to understand what 'value' means (Anderson \& Narus, 1998). Lindgreen and Wynstra (2005) offer a starting point for further research, but they also leave several gaps to be filled. This article therefore offers a comprehensive overview of cutting-edge research on the 'value' that businesses and industrial marketers analyze, create, and deliver. We begin by discussing value literature over time, including Lindgreen and Wynstra's (2005) value framework. We also propose extensions to this value framework and discuss avenues for further research.

\section{Literature review}

\subsection{Up to and around 2005}

Various research streams add to our understanding of value in business and industrial marketing. For example, the value analysis and engineering field recognizes that in competitive settings, long-term success hinges on offering the customer the best value for the price (Keith, 1960). Competition determines the direction a company must go to ensure value content in its goods or services. The producer's sense of 'value' differs from the user's; that is, for the same item, there are various kinds of value (Miles, 1961). Value is the minimum monetary cost to purchase or manufacture a product to create appropriate use and esteem values. These value studies thus focus on use value, or the lowest cost that will provide for the reliable performance of a function, and esteem value, or the lowest cost of providing the appearance and features that a customer wants.

Miles (1961) and others instead emphasize (product) value in relation to competition. The augmented product concept acknowledges different product aspects that can embody value 
for the customer, such that marketers must consider different product levels, each of which adds value for consumers (Levitt, 1969, 1980, 1981). Five levels are commonly defined: core benefit, expected product, augmented product, potential product, and final product (Kotler, 2003). The resulting consumer-value hierarchy applies equally well to goods, services, or any combination (Lovelock, 1994). Levitt's work thus was instrumental in emphasizing that customers may value product attributes beyond their immediate core benefits.

Most research that seeks to explain how product attributes translate into a certain value, or usefulness, of a product focuses on individual or household consumers. This stream defines 'value' as a preferential judgment, whereas 'values' refer to the criteria that determine those preferential judgments (Holbrook, 1994). Thus, consumer values are deeply held, enduring beliefs, whereas consumer value results from the trade-off of the benefits and sacrifices associated with a particular good or service (Holbrook, 1994). Researchers investigate how consumers make decisions and trade off benefits and sacrifices (Woodruff, 1997; Zeithaml, 1988). Marketers also work to understand consumers' values, preferences, or beliefs; measure and categorize consumer lifestyles (psychographics); and develop different classifications.

In research pertaining to the economic value of customers, existing customers are valuable assets to a company (Reichheld, 1996). Some customers have greater net present value than others, and the retention of unprofitable customers destroys value. The economic value of customers is an output of the value-creating process; customers are valuable to the company only if the company has something of value to offer them.

More recent marketing literature has developed two distinct research streams: the value of (augmented) goods and services, and the value of relationships. These streams in turn suggest several perspectives for industrial marketing.

2.1.1 Value of goods and services. Even in this category, there is no single, consensus definition of value. Zeithaml (1988) alone offers four definitions. Competitive advantage 
comes from the ability to give target customers an offer with more perceived value than competitors' offers (Doyle, 2000; Kotler, 2003). This perceived value consists of three elements: perceived benefits of the product minus both the product price and the costs of owning it.

This delivered value to customers thus can be measured as a difference, although customers do not always choose the offer with the highest delivered value (Kotler, 2003). For example, a business customer might have to buy at the lowest price; another might aim to maximize only personal benefits; or customers could enjoy a loyal relationship with a company and buy from it, almost regardless of the delivered value.

Neap and Celik (1999) argue that product value reflects the buyer's desire to obtain the product, which in turn depends on the affiliation of product details or performance with the buyer's value system. The value then is the cost of the product (i.e., total price paid), plus a subjective marginal value - a subjective measure that depends on the person's value system and can change. This definition clearly differs from others, in that the cost is not subtracted from benefits but rather offers a sort of objective indicator of those benefits.

To Anderson and Narus (1998), value is the monetary worth of the various benefits (e.g., technical, economic, service, social) a customer receives, compared with the price paid, taking into consideration competing suppliers' offerings. Value and price are independent; at least in business markets, the value provided nearly always exceeds the price, and the difference is the customer's incentive to purchase, such that price and value are two elemental product characteristics (Anderson, Thomson, \& Wynstra, 2000). Value excludes price in this definition; the benefits underlying value are net benefits, and costs incurred to obtain the benefits (except for purchase price) are included. The value of the same product varies for different customers, depending of its value in use in their usage situation. 
These definitions of value usually rely on monetary terms; other authors include other measures. Wilson and Jantrania (1994) measure value along economic, strategic, and behavioral dimensions. Woodruff's (1997) customer-value hierarchy links customer-desired value and customer satisfaction with received value. Customer-perceived value entails perceived preferences for and evaluations of product attributes, their performance, and the consequences of their use, which determine customers' ability to achieve their goals and purposes in usage situations. Customers want to maximize the perceived benefits and minimize the perceived sacrifices (money, time, effort). Ulaga and Chacour (2001) also adopt a supplier perspective to understand customers' perceptions of value.

2.1.2. Value of relationships. Companies do business not only to obtain the value of the good or service (Håkansson, 1982; Reichheld 1996) but also to enjoy attractive features of the offering, such as the reputation, location, or innovativeness of the supplier. Even future capabilities are valuable; the buyer can initiate a relation with this capable supplier and thus not need to change suppliers in the future, regardless of market shifts. This sort of relationship value extends beyond the actual product or service being exchanged.

The Contemporary Marketing Practice (CMP) group notes managers place greater emphasis on managing long-term relationships, networks, and interactions by focusing on their employees, customers (and their customers), suppliers (and their suppliers), and other markets (Coviello et al., 2002). Because marketing features a continuum of exchanges (Dwyer, Schurr, \& Oh, 1987), more value accrues through relational exchanges than transactional exchanges. Companies must examine all value-creation interactions in any customer relationship, as well as devote efforts to maintaining customer relationships.

Value creation does not take place in isolation, so the role of companies has changed, from providing customers with goods or services to designing systems of activities to help customers create value (Wikström, 1996). Sellers and buyers co-produce value; value 
innovation thus requires a company to combine its resources with others' capabilities and relationship quality thus becomes an important determinant of profitability (Webster, 2000; Grant, 2004).

A relationship also has value when (1) exchanges become predictable and reassuring as the partners learn to organize their business operations and (2) learning and adaptation in the relationship result in new solutions. For Walter, Ritter, and Gemünden (2001), this value entails the perceived trade-off among multiple benefits and sacrifices in a customer relationship, which may derive from the focal relationship or from connected networks on which the relationship has an impact. Suppliers must simultaneously offer value to and gain benefits from customers.

The activities performed and resources gained from customer relationships imply a functionalist paradigm (Anderson, Håkansson, \& Johanson, 1994), in which direct functions affect the partner company immediately, but indirect functions have a more ambiguous effect. The paradigm also indicates

- Direct functions include activities and resources that create value for the supplier, without depending on other relationships.

- All functions are direct; the effect is derived from a given relationship.

- Resources in a customer relationship have implications for a supplier's other exchanges.

- A customer relationship can fulfill more than one direct or indirect function.

- In a given relationship, indirect functions can be as important as the direct ones.

2.1.3. Perspectives on role of industrial and business marketing. Research has focused on the value of either the object or the process of exchange reflects two fundamentally different perspectives on the role of business and industrial marketing (Axelsson \& Wynstra, 2002). 
The first views the market system as fully functional and marked by perfect competition. Business and industrial marketing activities target relevant markets, and the number of alternative buyers and sellers represents the room for action, which depends on the standardization of the offering (a more unique offering creates lock-in effects). High termination costs mean the parties constantly analyze whether they can solve existing problems. Key commercial competencies include market knowledge and the ability to play the market. The market pushes for the use of existing competition and exploiting opportunities. This market structure thus supports a transactional approach to business and industrial marketing.

The second perspective regards markets as well-organized, connected networks (Axelsson \& Wynstra, 2002), so business and industrial marketing activities pertain to the relations across activities, ties among resources, and bonds between actors. Relationship functions are critical, including the customer's resource supply system and its significance for the company's position in various networks. The company focuses on specific customers, not vast market segments, with an emphasis on the contents and functions of a specific relationship in the larger network. This situation fosters practices in line with the relational approach.

Table 1 illustrates the main differences between transactional (competition) and relational (collaboration) exchange behavior (Axelsson \& Wynstra, 2002). Both perspectives represent distinct theoretical foci and ideas about the role of business and industrial marketing.

\section{...Insert Table 1 about here...}

In addition to the above, Lindgreen and Wynstra (2005) identified three major value themes in business and industrial marketing: value analysis (i.e., how do customers analyze value?), value creation (how can firms use value appraisals or tools like value engineering in market-oriented product development?), and value delivery (which actors create value, and 
which delivery process provides the best value for which customers?) When the two perspectives are crossed with the three themes, six potential areas for research emerged.

\subsection{Post-2005}

As the debate on value continued past 2005, Industrial Marketing Management has acted in a central role in following and shaping the landscape. Much of the cutting edge analysis of our understanding of value has been played out in the journal, as can be noted from its predominance as source amongst the papers identified in this section. As seen above, Lindgreen and Wynstra (2005) categorized the different approach to understanding value derived from goods and services and value from buyer-seller relationships, and this has been a precursor for more recent knowledge development concerning understanding value.

Attention from scholars and practitioners previously has been paid to value creation from the supplier side and from the buyer perspective according to interest and orientation. Certainly, interest in the business to business world has been on value creation (Möller, 2006) as core to the purpose of exchange (Vargo \& Lusch, 2008a) and Eggert, Ulaga, and Schultz (2006), for example, neatly determine the nature and process of value creation.

The debate has progressed further in recognizing the importance of relationships and the understanding and building of value in a business relationship context (Ulaga \& Eggert, 2006; Palmatier, 2008) and the greater significance attached to relationship benefits over relationship costs in the creation of value (Ulaga \& Eggert, 2006). Relationship value is a measure of joint outputs (Ballantyne et al., 2011; Palmatier, 2008; Ulaga \& Eggert, 2006), underpinned by co-operation (Walters \& Rainbird, 2007), where the nature of the interaction between supplier and customer is critical (Corsaro \& Snehota, 2010; Edvardsson, Tronvoll, \& Gruber, 2010; Grönroos, 2008, 2010) in the creation of joint value (Payne, Storbacka, \& Frow, 2008). Development of a service view of value creation is to the fore, as to be seen in the often cited work of Vargo and Lusch. 
Their primary paper (Vargo \& Lusch, 2004) outlined a manifesto of service-dominant logic (S-DL) centred on the co-creation of value through inter-linked resources, engagements and actors, and was refined further in subsequent publications (Vargo \& Lusch, 2008a, 2008b). Grönroos $(2008,2011)$ also espouses services logic. The basis of these approaches is that value is not created by exchange, but in joint co-creation and demonstrated as value in use (customer value created between parties) rather than that of goods as in a goods-dominant logic, or GD-L (Vargo \& Lusch, 2004) delivered by suppliers (Anderson \& Narus, 2004); with both seller and customer involved in the process of value creation through service (Ballantyne et al., 2011; Grönroos, 2008; Macdonald et al., 2011; Payne et al., 2008;).

Ultimately, Vargo and Lusch (2008b) see this co-creation as beyond the distinction of individual organizations. This echoes prior relationship marketing (RM) origins in business to business (see, for example, Lindgreen, 2008; Day, 2000), and is perhaps similar in view to those in earlier times espousing the benefits of engaged and partnered embeddedness in seamless co-creation of organizations bound together in progressively embedded bonding and 'partnering' and 'value adding partnerships' (see Webster, 1992). This is perhaps idealistic, and indeed some would call for more refinement through practical application, beyond the theory of S-DL (for example, Ballantyne et al., 2011).

A further extension of co-creation between seller and buyer is to see value in the wider stakeholder and network context (Frow \& Payne, 2011) rather than simple-buyer seller dyad or integration. For example, Fiol et al. (2011) develop value perspectives from a cluster viewpoint and others see the need to place this in an interaction based framework; as demonstrated in the Industrial Marketing and Purchasing (IMP) group approach. Ford (2011), for example, draws conclusions from comparison with and analysis of SD-L and the longer standing IMP interactionist tradition, whereby value is co-created in the interaction process of both focal dyads and wider network structures. 
This drawing together of two research schools of thought is useful. The SD-L approach that has recently been predominant has re-iterated the importance of relationship value and co-creation, but does not re-shape the landscape occupied by relationship marketing, services marketing, interactionism and other foci of interest that have gone before. Further, the recent view in Vargo and Lusch (2011) that all actors (firms, customers) are busily serviceproviding and value co-creating, could be seen as unrealistic. Not all businesses are committed to joint chain and network interaction and thereby value co-creation, and there are other significant factors in play that shape value relationships and more importantly motives of businesses to create value; and their approaches to dispersal of value accrued from relationships.

Organizations seeking to enhance relationship value (and with an emphasis on the disproportionate share of the value accruing to themselves) put varying degrees of effort into maintaining business relationships from somewhat transactional to full collaboration (Grant, 2005). The effort expended in relationship building and maintenance will alter between organizations according to the relative importance of the relationship to each party and even during the course of an existing relationship (Cox, 2004; Hingley, 2005a). Businesses will be conscious of switching and transaction costs when seeking to maintain relationships and build joint value (Gounaris, 2005).

Similarly, Blocker et al. (2011) and Ulaga and Eggert (2006) see (customer) creation of value as a trade-off between benefts and sacrifices in their dealings with suppliers. This should also be seen in the context of power in business relationships (Hingley, 2005a, 2005b; Kumar, 2005) where most business exchanges are power-imbalanced and the powerful party/ parties seek and expect a disproportionate share of the surplus value (Cox, 2004) from the relationship. In turn the power dynamic and power-play of suppliers and buyers impact on the possibilities, approach and desire for value co-creation (Hingley, 2005a). 
This does not mean that power is always a negative force and weaker parties (usually suppliers) have a way of with living with powerful ones (usually buyers) (Hingley, 2005a) and, as above, may see power trade-off as sacifice for reduced transaction costs derived from regular business with a more powerful party and regular (although as weaker party, lesser) returns derived from relationship value. So, it is not just the creation of value that is significant in business relatonships, but the continuity of the relationship, the trust and commitment within it (Morgan \& Hunt, 1994), and the consequent saving in transaction costs that is important. Businesses, in recognising their relatively weaker position in a relationship will trade-off and sacrifice (monetary) value, for ongoing and regular business with consequent reductions in transaction costs.

The issue of relationship power is part of the context of the debate over creation of value in a supply chain and network framework as identified in for example, Duffy (2008) and Cox (2004). There is an increased marrying of supply chain management and relationship literature with marketing and value-creation/ service literature (see, for example, Christopher, 2011; Grant, 2004) and this has produced a more holistic view of our understanding of value across several actors as well as provide useful practical and empirical understanding. A good example of this is work on value chain analysis, which is actioning and updating Michael Porter's classic work (1985) and concerns the undertaking of analysis of all activities in the chain and network and identifies opportunities and strategies for co-creation of value. While Ravald and Grönroos (1996) were one of the first to recognize a relationship between value chain analysis and relationship marketing, practical extensions to their work in supply chain management have been undertaken by Barber (2008) on value measurement, Glaser (2008) on the role of branding and co-branding to align value chain activities, and Win (2008) on how fourth-party logistics service providers can add value in the supply chain for buyers and sellers. 
Further, understanding of collaborative buyer-seller relationships is central to the understanding of value creation between businesses. This is well developed in literature which bridges source literature on relationship marketing and supply chain relationships, for example, as outlined in Grant (2005), Hingley (2005b), Hingley, Lindgreen, and Casswell (2006), Narayandras and Rangan (2004) and Cox (2004). Astrup, Grant, and Bjerre (2007) further consider value creation in retailer supplier relationships via the of concept of category management in which, and with reference here again to the power-dependency issue, value is created by powerful buyers and their nominated product category grouping suppliers in 'partnered' relationships. Astrup, Grant, and Bjerre (2007) argue that although category management is mired in power-dependency, joint value can be achieved; such that category management is an actioning of relationship value development.

Attention also recently has focued on buyers establishing key supplier relationships, see for example Ulaga and Eggert (2006) and Eltantawy et al. (2009), which may be considered a 'mirror image' of relationship marketing and thus arracts similar benefits. Thus, buyers or customers developing key supplier relationships also have an opportunity to co-create value with suppliers to ensure products or services are fit for purpose and maintain security of supply, particularly across global markets. This area of work is under-developed at present but is seeing increased activity in light of current issues concerning the economic recession and ethical and sustainable sourcing.

\section{Avenues for further research}

The foregoing discussions have highlighted the changes in our notions of value. While the original six-element framework of Lindgreen and Wynstra (2005) still has merit, new areas for consideration have emerged that should drive future research. Figure 1 presents these areas under the three stages of analysis, creation and delivery. Lindgreen and Wynstra's concepts of transaction and relationships are more appropriately presented as the value 
proposition, reflecting the increased importance of services, and relationship form, reflecting the now-accepted view that relationships are essential in the value process.

Issues for analysis for the value proposition are short-term and transactional and lead to the creation of market responsive and timely propositions. Delivery is provided on an effective but efficient basis due to the lack of longer-term relationships providing enhanced profitability over time. Similarly, analysis for relationship form will include long-term considerations and consistency, creation will determine the proper form of pro-active management of the product or service, and delivery will require loyalty and trust between partners that should also enhance each other's brands.

Five other areas for consideration synthesized from the discussions above include capabilities management, value metrics, the temporal horizon, innovation imperatives, and a tactical focus.

\section{...Insert Figure 1 about here...}

Capabilities management is concerned with a firm's abilities to create and provide value in conjunction with its partner to meet market requirements in a wider supply chain or value chain context, and very much reflects a matching exercise that may determine the extent of relational power; i.e. the partner with the greater capabilities may have more power.

The issue of value metrics continues to be important and future work should continue to examine how firms develop, monitor and assess metrics. For example, what are customers and ultimate consumers really demanding, particularly in these difficult economic times?

The temporal horizon is different from the relational form; firms can have transactionbased relationships that are interrupted temporally, e.g. seasonal buying and provision at certain times of the year. Challenges here include finding like-minded partners and then executing on an efficient and effective basis. 
The fast-pace of markets today also demand continuous innovation or improvement in the value proposition; however is that really the case and how do we know? Given the necessity for innovation though, firms must assess their resources and capabilities to be innovative and develop such innovations with their partners to again increase benefits to all as well as their respective brands.

Lastly, the tactical focus is related to the temporal horizon but is more strategic in nature in order to develop appropriate short versus long-term goals. In fast-moving consumer goods markets this may mean recognizing the increasingly short-term nature of product or service life cycles that require firms to get in and then get out of the market before demand changes towards possibly more innovative or meaningful products and services. For example, no manufacturer or retailers wants to hold large inventories of the latest versions of Apple's iPad when the new version comes onto the market.

While not necessarily exhaustive, this framework nevertheless provides fertile ground for research that should deepen our understanding of how value is analyzed, created and delivered among firms in wider and global supply chains. These framework constructs also relate to the value-based research priorities set out by the Institute for the Study of Business Market (ISBM, 2011), which poses inter alia the following research questions:

- What are the best ways to conceptualize and understand customer value?

- How do you get beyond the buyer to identify the values of the right people in the buyer's firm?

- What approaches and measurement methods exist, can be adapted, or can be developed to assess customer value in business markets?

- How can the value of the core product or service and its augmenting services, programs, and systems be separately assessed?

- How do and how should buyers assess the value of alternative suppliers' market offerings? 
- How are value, quality, and customer satisfaction conceptually and empirically related?

- How can we measure the value of collaborative relationships with customers?

Further considerations that are overarching and not specifically mentioned in the framework, but affect all its elements, include the ongoing debate about power, trust, commitment; as well as a growing concern for the environment, ethics and corporate and social responsibility. In summary, there is wide scope for research to refine these elements and also add new ones going forward in this new decade and beyond.

\section{Managerial implications}

Deriving implications for value analysis, value creation, and value delivery in business and industrial marketing requires reflection upon the state-of-the-art in terms of managerial practice. Fifteen years ago, Flint and Woodruff (1997) bemoaned the fact that they could offer little normative advice for managers seeking to understand how the concept of value and managerial perceptions of value were changing. They sought to respond to this lacuna by developing a customer value change theory and, in so doing, they presented a call for new research that could underlie managerial prescriptions of value change.

Since that time, the value movement has evolved and a proliferation of interest in the concept of value in business markets has been witnessed (Ramani \& Kumar, 2008). Nowadays, the virtues of value are extolled by many: consultancies peddle their value solutions-focused diagnostics, tools, and techniques; normative advice is offered by academicians; managerial prescriptions are conveyed by thought leaders; and, airport bookstores carry several, mostly competing, treatises from value creators. Advice is seemingly ubiquitous. However, managers seek this advice despite their appetite being rarely nourished.

Based on the value analysis, value creation, and value delivery framework depicted in this article, we present a process model for value orchestration in business and industrial markets 
(Figure 2). Founded upon the resource-based view of the firm, we contend that resources are instrumental to value creation based upon the development of competitive advantages (Ireland, Hitt, \& Sirmon, 2003). However, the mere possession of resources is a first principle and so managers need to accumulate, combine and exploit their resource base in order to realize value (Sirmon, Hitt, \& Ireland, 2007). In the following section, we overlay this managerial process of resource management (presented as three managerial resource activities — structuring, bundling, and leveraging) upon the value analysis, value creation, and value delivery framework in a bid to articulate a series of managerial prescriptions for value creation.

\section{...Insert Figure 2 about here...}

Focusing upon the role that managers play in managing resources, Sirmon, Hitt, \& Ireland (2007) identified three discrete but related activities that collectively focus on creating value for customers and competitive advantages for firms. The first of these is structuring activities, which itself has three sub-processes for managerial decision making: acquiring, accumulating, and divesting resources that create the firm's resource portfolio. Second, by integrating resources managers are able to respectively improve, extend, and create capabilities by the three sub-processes that characterize bundling activities: stabilizing, enriching, and pioneering processes. Finally, in order to capitalize upon these capabilities and exploit market opportunities, managers engage in one or a combination of three subprocesses within leveraging activities: mobilizing, coordinating, and deploying.

We posit that these three activities collectively form the basis of value orchestration. Structuring activities establish the norms and basis for value analysis. Determining the resources available to managers through their acquisition, accumulation, and divestiture establishes a resource portfolio that enables coherent analysis of value to be calculated and 
customer needs understood. Key metrics can then be established to map the role that resources will play in understanding value analysis $(\mathrm{Li}, 2011)$.

Bundling activities, in turn, enable value creation to be established. By integrating the resources available, managers can improve, extend, and create capabilities that result in development solutions to be created, innovations to occur (Lilien, Grewal, Ding, Bowman, Griffin, Kumar, Narayandas, Peres, \& Srinavasan, 2009) and shared value to be engendered (Porter \& Kramer, 2011).

Finally, in order to action value delivery, managers need to leverage their resources by executing decisions that mobilize, coordinate, and deploy them in efficient and effective ways. This form of leveraging is essential in order to delineate clearly the value proposition and provide a total customer offering (Grönroos, 2011; Vargo \& Lusch, 2011) that satisfies customer needs. It is important to note here that clear value delineation, which is characterized as value quantification and value communication, was voted the \#1 trend in a recent survey of business and industrial managers (ISBM, 2011). Indicative managerial protestations are as follows: "Business marketers need to produce new ways of demonstrating the value their solutions offer in the customer's business"; "Our biggest challenge is deepening our relationship with customers and helping them see the total value proposition we deliver to them - including but not solely driven by innovation and what did holistically is worth to their business versus just evaluating us on a per-item quote versus a competitor" (ISBM 2011, p. 9).

\section{Closing remarks}

It is hoped that this review of research literature on value in business and industrial marketing, the identification of areas that should drive future research, and the suggested process model for value orchestration all have helped to a clearer understanding of what we 
know about value in business and industrial marketing and how research could be driven further.

\section{References}

Aastrup, J., Grant, D.B., \& Bjerre, M. (2007). Value creation and category management through retailer-supplier relationships. International Review of Retail, Distribution and Consumer Research, 17 (5), 523-541.

Anderson, J.C. \& Narus, J.A. (1998). Business marketing: understand what customers value. Harvard Business Review 76 (6), 53-65.

Anderson, J.C. \& Narus, J.A. (2004). Business market management: understanding, creating, and delivering value, 2nd ed., Upper Saddle River (NJ): Prentice Hall.

Axelsson, B. \& Wynstra, F. (2002). Buying Business Services, John Wiley \& Sons, Chichester.

Ballantyne, D., Frow, P., Varey, R.J., \& Payne, A. (2011. Value propositions as communication practice: Taking a wider view. Industrial Marketing Management, 40 (2), 202-210.

Barber, E. (2008). How to measure the "value" in value chains. International Journal of Physical Distribution \& Logistics Management. 38 (9), 685-698.

Blocker, C.P., Flint, D.J., Myers, M.B., \& Slater, S.F. (2011). Proactive customer orientation and its role for creating customer value in global markets. Journal of the Academy of Marketing Science, 39 (2), 16-233.

Christopher, M. (2011). Logistics and Supply Chain Management: Creating Value-adding Networks, 4th ed., Pearson Education, Harlow.

Corsaro, D. \& Snehota, I. (2010). Searching for relationship value in business markets: Are we missing something? Industrial Marketing Management, 39 (6), 986-995. 
Cox, A. (2004). Business relationship alignment: on the commensurability of value capture and mutuality in buyer and supplier exchange. Supply Chain Management: An International Journal, 9 (5), 410-420.

Day, G. (2000). Managing marketing relationships. Journal of the Academy of Marketing Science, 28 (1), 24-30.

Doyle, P. (2000). Value-Based Marketing: Marketing Strategies for Corporate Growth and Shareholder Value, John Wiley \& Sons, Chichester.

Duffy, R.S. (2008). Towards a better understanding of partnership attributes: An exploratory analysis of relationship type classification. Industrial Marketing Management, 37 (2), 228244.

Edvardsson, B., Tronvoll, B., \& Gruber, T. (2010). Expanding understanding of service exchange and value co-creation: A social construction approach. Journal of the Academy of Marketing Science, 39 (2), 327-339.

Eggert, A., Ulaga, W., \& Schultz, F. (2006). Value creation in the relationship life cycle: A quasi-longitudinal analysis. Industrial Marketing Management, 35 (1), 20-27.

Eltantawy, R.A., Giunipero, L., \& Fox, G.L. (2009). A strategic skill based model of supplier integration and its effect on supply management performance. Industrial Marketing Management, 38 (8), 925-936.

Fiol, L.J.C., Alcañiz, T., M.A.M., \& García, J.S. (2011). Multidimensional perspective of perceived value in industrial clusters, Journal of Business \& Industrial Marketing, 26 (2), $132-145$.

Flint, D.J. \& Woodruff, R.B. (1997). Customer value change in industrial marketing relationships: A call from new strategies and research. Industrial Marketing Management, $26(2), 163-175$. 
Ford, D. (2011). IMP and service-dominant logic: Divergence, convergence and development. Industrial Marketing Management, 40 (2), 231-239.

Frow, P. \& Payne, A. (2011). A stakeholder perspective of the value proposition. European Journal of Marketing, 45 (1/2), 223-240.

Glaser, S. (2008) The role of branding in the value chain. International Journal of Physical Distribution \& Logistics Management. 38 (9), 726-736.

Gounaris, S.P. (2005). Trust and commitment influences on customer retention: insights from business-to-business services. Journal of Business Research, 58 (2), 126-140.

Grant, D.B. (2004). UK and US management styles in logistics: Different strokes for different folks? International Journal of Logistics: Research and Applications, 7 (3), 181197.

Grant, D.B. (2005). The transaction-relationship dichotomy in logistics and supply chain management. Supply Chain Forum: An International Journal, 6 (2), 38-48.

Grönroos, C. (2008). Service logic revisited: Who creates value and who co-creates? European Business Review, 20 (4), 298-314.

Grönroos, C. (2010). A service perspective on business relationships: The value creation, interaction and marketing interface. Industrial Marketing Management, 40 (2), 240-247.

Grönroos, C. (2011). A service perspective on business relationships: The value creation, interaction and marketing interface. Industrial Marketing Management, 40 (3), 240-247.

Hingley, M.K. (2005a). Power to all our friends? Living with imbalance in supplier-retailer relationships. Industrial Marketing Management, 34 (8), 848-858.

Hingley, M.K. (2005b). Power imbalance in UK agri-food supply channels: Learning to live with the supermarkets? Journal of Marketing Management, 21 (1/2), 63-68. 
Hingley, M.K., Lindgreen, A., \& Casswell, B. (2006). Supplier-retailer relationships in the UK fresh produce supply chain. Journal of International Food and Agribusiness Marketing, 18 (1/2), 49-86.

Hunt, S.D. (2000). A General Theory of Competition, Sage Publications, Thousand Oaks, CA.

Ireland, R.D., Hitt, M.A., \& Sirmon, D.G. (2003). A model of strategic entrepreneurship: The construct and its dimensions. Journal of Management, 29, 963-989.

ISBM (2011). Insights into action: ISBM B-to-B marketing trends. Institute for the Study of Business Markets. University Park, PA: Pennsylvania State University.

Kotler, P. \& Keller, K.L. (2008). Marketing Management, 13th international ed., Prentice Hall, London.

Kumar, N. (2005). The power of power supplier-retailer relationships. Industrial Marketing Management, 34 (7), 863-866.

Li, L.-Y. (2011). Marketing metrics' usage: Its predictors and implications for customer relationship management. Industrial Marketing Management, 40 (1), 139-148.

Lilien, G.L., Bowman, D., Griffin, A., Kumar, V., Narayandas, D., Peres, R., \& Srinivasan, R. (2009). Calculating, creating, and claiming value in business markets: Status and research agenda. ISBM Report, 5-2009, Institute for the Study of Business Markets, University Park, PA: Pennsylvania State University.

Lindgreen, A. (2008). Managing Market Relationships, Gower Publishing, Farnham.

Lindgreen, A. \& Wynstra, F. (2005). Value in business markets: What do we know? Where are we going? Industrial Marketing Management 34 (7), 732-748.

Macdonald, E.K., Wilson, H., Martinez, V., \& Toossi, A. (2011). Assessing value-in-use: A conceptual framework and exploratory study. Industrial Marketing Management, 40 (5), 671-682. 
Möller, K. (2006). Role of competences in creating customer value: A value-creation logic approach. Industrial Marketing Management, 35 (8), 913-924.

Morgan, R.M. \& Hunt, S.D. (1994). The commitment-trust theory of relationship marketing. Journal of Marketing, 58 (3), 20-38.

Narayandras, D. \& Rangan, V.K. (2004). Building and sustaining buyer-seller relationships in mature industrial markets. Journal of Marketing, 68 (3), 63-7.

Palmatier, R.W. (2008). Interfirm relational drivers of customer value. Journal of Marketing, $72(7), 76-89$.

Payne, A.F., Storbacka, K., \& Frow, P. (2008). Managing the co-creation of value. Journal of the Academy of Marketing Science, 36 (1), 83-96.

Porter, M.E. (1985). Competitive Advantage: Creating and sustaining superior performance, Free Press, New York.

Porter, M. E. \& Kramer, M. R. (2011). Creating shared value. Harvard Business Review, 89 $(1 / 2), 62-77$.

Ramani, G. \& Kumar, V. (2008). Interaction orientation and firm performance. Journal of Marketing, 72 (Jan), 27-45.

Ravald, A. \& Grönroos, C. (1996). The value concept and relationsip marketing. European Journal of Marketing, 30, (2), 19-30.

Sirmon, D.G., Hitt, M.A., \& Ireland, R.D. (2007). Managing firm resources in dynamic environments to create value: Looking inside the black box. Academy of Management Review, 32 (1), 273-292.

Ulaga, W. \& Eggert, A. (2006). Value-based differentiation in business relationships: Gaining and sustaining key supplier status. Journal of Marketing, 70 (1), 119-136.

Vargo, S.L. \& Lusch, R.F. (2004). Evolving to a new dominant logic for marketing. Journal of Marketing, 68 (1), 1-17. 
Vargo, S.L. \& Lusch, R.F. (2008a). Service-dominant logic: Continuing the evolution. Journal of the Academy of Marketing Science, 36 (1), 1-10.

Vargo, S.L. \& Lusch, R.F. (2008b). From goods to service(s): Divergences and convergences of logics. Industrial Marketing Management, 37 (3), 254-259.

Vargo, S.L. \& Lusch, R.F. (2011). It's all B2B... and beyond: Towards a systems perspective of the market. Industrial Marketing Management, 40 (2), 181-187.

Walters, D. \& Rainbird, M. (2007). Strategic Operations Management: A Value Chain Approach, Palgrave Macmillan, Houndmills.

Webster, F.E. (1992). The changing role of marketing in the corporation. Journal of Marketing, 56 (3), 1-17.

Win, A. (2008). The value a 4PL provider can contribute to an organisation. International Journal of Physical Distribution \& Logistics Management, 38 (9), 674-684. 


\section{Biographical Sketches}

\section{Adam Lindgreen}

Dr. Adam Lindgreen is Professor of Marketing at the University of Cardiff's Business School. Dr. Lindgreen received his Ph.D. from Cranfield University. He has published in the California Management Review, the Journal of Business Ethics, the Journal of Product and Innovation Management, and the Journal of the Academy of Marketing Science, among others. Among his most recent books are Managing Market Relationships (Gower Publishing, 2008) and Memorable Customer Experiences (Gower Publishing, 2009). His research interests include business and industrial marketing, experiential marketing, and corporate social responsibility. The recipient of the "Outstanding Article 2005" award from Industrial Marketing Management and the Christer Karlsson Award at the 2007 International Product Development Management conference, Dr. Lindgreen serves on the boards of many journals; he is the joint editor of the Journal of Business Ethics for the section on corporate responsibility.

\section{Martin K. Hingley}

Dr. Martin K. Hingley is Professor of Strategic Marketing at the University of Lincoln's Business School. Dr. Hingley's research interests are in marketing and supply chain management. He has presented and published widely in these areas, including in Industrial Marketing Management, the Journal of Marketing Management, and Supply Chain Management: An International Journal. He serves on the board of several international academic journals and also regularly guest edits academic journals. Dr. Hingley has broad business experience in the international food industry and has spent some time in provision of market and business analysis and industry-based training with the Institute of Grocery Distribution (IGD), and previously held a three-year fellowship with global retail chain Tesco Plc. 


\section{David B. Grant}

Professor David B. Grant is Director of the Logistics Institute in the Business School at the University of Hull in the UK. His doctoral thesis at the University of Edinburgh investigated customer service, satisfaction, and service quality in UK food processing logistics and received the James Cooper Memorial Cup PhD Award from the Chartered Institute of Logistics and Transport (UK) in 2003. Professor Grant has over 125 publications in various refereed journals, books, and conference proceedings, regularly referees articles for many academic journals and conferences, and is on the editorial board of six international academic journals. He is a member of the Council of Supply Chain Management Professionals (CSCMP) and its Education Strategies Committee, the UK Logistics Research Network (LRN), the Nordic NOFOMA logistics research group, and the British Retail Consortium's Storage and Distribution Technical Advisory Committee.

\section{Robert E. Morgan}

Dr. Robert Morgan holds the Sir Julian Hodge Chair and is Professor of Marketing \& Strategy at Cardiff Business School, Cardiff University. He has been Visiting Scholar at INSEAD and holds visiting professorships at other European Schools. He is a Chartered Marketer and a Fellow of both the Higher Education Academy and Chartered Institute of Marketing. He serves on the Editorial Advisory Board of several international journals; his main research interests focus on the marketing and strategy interface and new product development with articles from his recent work appearing in Industrial Marketing Management, the Journal of Business Research, the Journal of International Marketing, the Journal of Management Studies, the Journal of the Academy of Marketing Science, and the Strategic Management Journal. 
Table 1: Transactional versus relational marketing and purchasing behavior (adapted from Axelsson and Wynstra [2002])

\begin{tabular}{|c|c|c|}
\hline Perspective & Transactional & Relational \\
\hline Competition & Many alternatives & One or few alternatives \\
\hline Tactical focus & $\begin{array}{l}\text { Every deal is a new business; no } \\
\text { one benefits from past } \\
\text { performances; market exchanges } \\
\text { are independent and discrete }\end{array}$ & $\begin{array}{l}\text { A deal is part of a relationship, and } \\
\text { the relationship is part of a } \\
\text { network; dependent, ongoing } \\
\text { market exchanges }\end{array}$ \\
\hline Relationship attitude & $\begin{array}{l}\text { Exploit the potential of } \\
\text { competition; anonymous and } \\
\text { efficient market }\end{array}$ & $\begin{array}{l}\text { Exploit the potential of } \\
\text { cooperation; numerous market } \\
\text { networks }\end{array}$ \\
\hline Temporal horizon & $\begin{array}{l}\text { Short-term, arm's-length, avoid } \\
\text { coming too close }\end{array}$ & $\begin{array}{l}\text { Long-term, tough demands, joint } \\
\text { development }\end{array}$ \\
\hline $\begin{array}{l}\text { Organizational } \\
\text { structure }\end{array}$ & $\begin{array}{l}\text { Hierarchical, functional } \\
\text { organization }\end{array}$ & $\begin{array}{l}\text { Cross-functional, process-based } \\
\text { organization }\end{array}$ \\
\hline Renewal & $\begin{array}{l}\text { Effective renewal through partner } \\
\text { changes, choose the most efficient } \\
\text { supplier at any time }\end{array}$ & $\begin{array}{l}\text { Effective renewal through } \\
\text { collaboration and teamwork; } \\
\text { combine resources and knowledge }\end{array}$ \\
\hline Innovation imperative & Buying standardized products & $\begin{array}{l}\text { Buying capabilities; customized } \\
\text { products }\end{array}$ \\
\hline Services & Services augment the core product & $\begin{array}{l}\text { Services are basis for } \\
\text { differentiation }\end{array}$ \\
\hline Orientation & $\begin{array}{l}\text { Price orientation, to achieve } \\
\text { favorable prices in well-specified } \\
\text { products; marketing through the } \\
\text { 4Ps }\end{array}$ & $\begin{array}{l}\text { Cost and value orientation, to } \\
\text { achieve low total costs of supply; } \\
\text { develop new value; marketing } \\
\text { through relationships, networks, } \\
\text { interactions }\end{array}$ \\
\hline
\end{tabular}




\begin{tabular}{|c|c|c|c|}
\hline $\begin{array}{c}\text { Value } \\
\text { proposition }\end{array}$ & $\begin{array}{l}\text { Short-term; } \\
\text { Transactional }\end{array}$ & $\begin{array}{c}\text { Market } \\
\text { Response; } \\
\text { Timeliness }\end{array}$ & $\begin{array}{l}\text { Efficiency; } \\
\text { Effectiveness }\end{array}$ \\
\hline $\begin{array}{l}\text { Relationship } \\
\text { form }\end{array}$ & $\begin{array}{l}\text { Long-term; } \\
\text { Consistency }\end{array}$ & $\begin{array}{l}\text { Managed; Pro- } \\
\text { active }\end{array}$ & $\begin{array}{l}\text { Loyalty and Trust; } \\
\text { Brand }\end{array}$ \\
\hline $\begin{array}{l}\text { Capabilities } \\
\text { management }\end{array}$ & $\begin{array}{c}\text { Internal } \\
\text { Capabilities }\end{array}$ & $\begin{array}{c}\text { Match to } \\
\text { External } \\
\text { Capabilities }\end{array}$ & $\begin{array}{l}\text { Track with } \\
\text { Partners }\end{array}$ \\
\hline $\begin{array}{l}\text { Value } \\
\text { metrics }\end{array}$ & $\begin{array}{l}\text { Importance to } \\
\text { the Firm }\end{array}$ & $\begin{array}{l}\text { Importance to } \\
\text { Supply Chain }\end{array}$ & $\begin{array}{l}\text { Monitor and } \\
\text { Assess Metrics }\end{array}$ \\
\hline $\begin{array}{l}\text { Temporal } \\
\text { horizon }\end{array}$ & $\begin{array}{c}\text { Transaction } \\
\text { versus } \\
\text { Relationships }\end{array}$ & $\begin{array}{c}\text { Finding } \\
\text { Like-minded } \\
\text { Partners }\end{array}$ & $\begin{array}{c}\text { Efficiency; } \\
\text { Effectiveness }\end{array}$ \\
\hline $\begin{array}{l}\text { Innovation } \\
\text { imperative }\end{array}$ & $\begin{array}{l}\text { Requirements } \\
\text { and Capabilities }\end{array}$ & $\begin{array}{c}\text { Develop with } \\
\text { Partners }\end{array}$ & $\begin{array}{c}\text { Benefits and } \\
\text { Brand }\end{array}$ \\
\hline \multirow[t]{2}{*}{$\begin{array}{l}\text { Tactical } \\
\text { focus }\end{array}$} & $\begin{array}{l}\text { Short versus } \\
\text { Long-term }\end{array}$ & $\begin{array}{c}\text { Finding } \\
\text { Like-minded } \\
\text { Partners }\end{array}$ & $\begin{array}{l}\text { Review and } \\
\text { Assess Goals }\end{array}$ \\
\hline & Analysis & Creation & Delivery \\
\hline
\end{tabular}

Figure 1: The extended value framework 

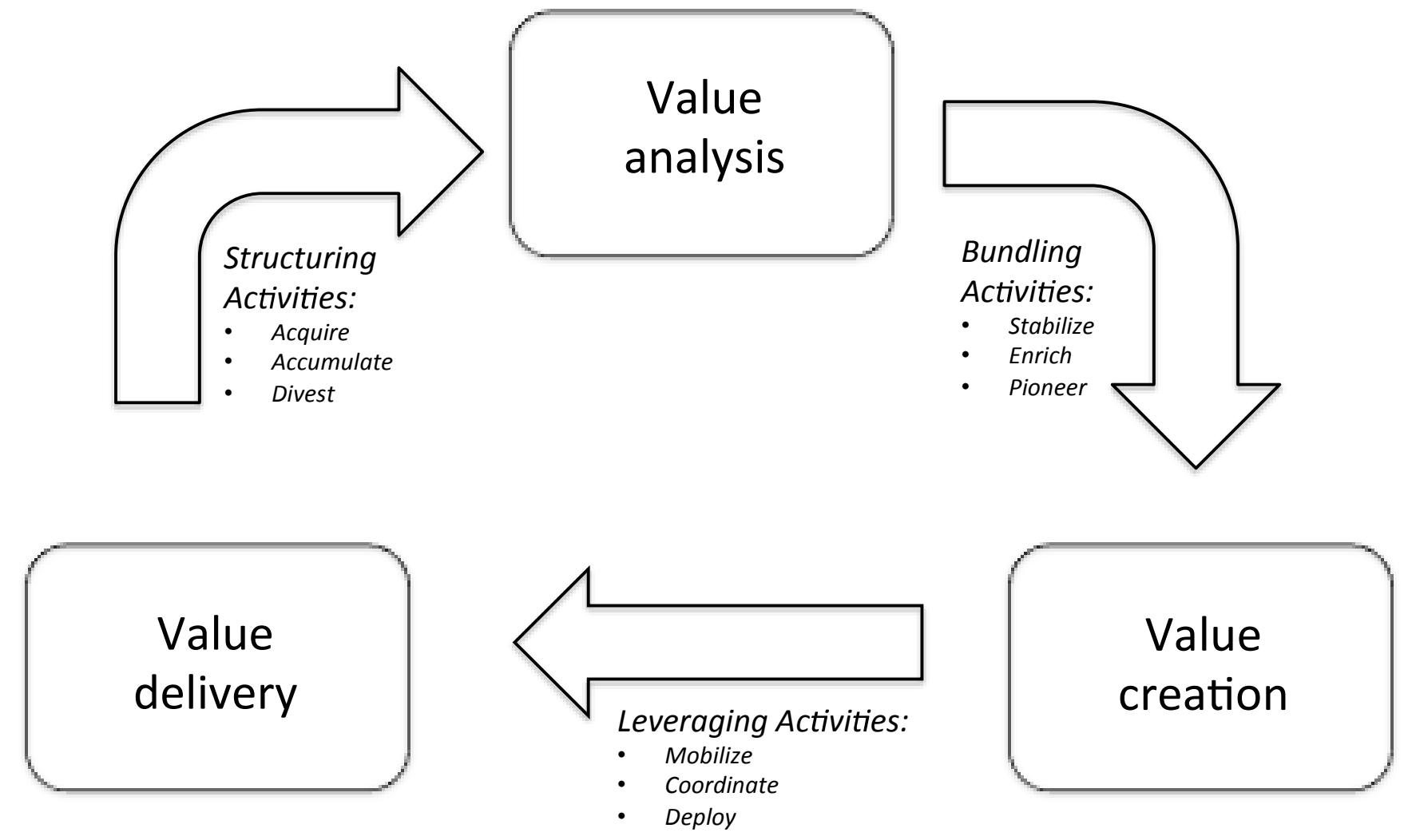

Figure 2: Value orchestration in business and industrial markets: managerial priorities 